\title{
PENGARUH PENDEKATAN BERPIKIR KAUSALITIK BER-SCAFFOLDING DENGAN PEMBERIAN TUGAS PENDAHULUAN TERHADAP KEMAMPUAN PEMECAHAN MASALAH SISWA SMA
}

\author{
Roni Abdani*, Joni Rokhmat, Satutik Rahayu \\ Program Studi Pendidikan Fisika, Universitas Mataram \\ *Email: roni.fis2014@gmail.com
}

\begin{abstract}
This research aims to discover the effect of scaffolding causalitic thinking approach with preliminary task toward impulse and momentum student's problem solving ability (PSA) at X grade. The type of this study is quasi experimental research with post-test only control group design. The research population is all student's of X MIA SMAN 8 Mataram with 33 chosen students from X MIA 1 as experimental class and 32 chosen students from X MIA 3 as control class as the sample by using cluster random sampling. Based on the research finding, it is found that the average score of problem solving ability in experimental class is 65, while the average score of PSA in control class is 53. The PSA data of two classes were normal distributed. According to the result of homogeneity test, it was obtained that both are homogen. The PSA data were analyzed with t-test polled varians. The data analysis showed that $t_{\text {count }}$ was 3,3690 and table with significant rate (5\%) was 1,9987 which means $t_{\text {count }}>t_{\text {table. Based }}$ on that fact, it can be concluded that there is an effect of scaffolding causaliticthinking approach with preliminary tasks toward PSA impulse and momentum students at X grade.
\end{abstract}

Keywords: Scaffolding, Causalitic Thinking Approach, Preliminary Task, Problem Solving Ability, Impulse, Momentum

\section{PENDAHULUAN}

Pendidikan merupakan sarana untuk meningkatkan kualitas sumber daya manusia agar memiliki daya saing yang wajar sesuai dengan kemampuan akademiknya. Pendidikan dalam pengertian yang lebih sederhana dapat diartikan sebagai usaha guru untuk menumbuhkan dan mengembangkan potensi-potensi pembawaan. Salah satu aspek yang dapat dikategorikan sebagai potensi pembawaan adalah aspek kecakapan. Siswa yang memiliki potensi kecakapan dapat diidentifikasi dengan melihat bagaimana tingkat kemampuan pemecahan masalah siswa tersebut.

Kemampuan pemecahan masalah merupakan bagian dari pembelajaran yang sangat penting karena dalam proses pembelajaran maupun penyelesaiannya, siswa dimungkinkan untuk memperoleh pengalaman menggunakan pengetahuan yang sudah dimiliki. Menurut Venisari et al. (2015) Kemampuan pemecahan masalah merupakan salah satu kemampuan kognitif tingkat tinggi yang memungkinkan siswa memperoleh pengetahuan dan keterampilan. Sementara itu, Rokhmat (2013) mengungkapkan bahwa kemampuan pemecahan masalah (KPM) adalah kemampuan siswa untuk menggunakan pengetahuan yang dimilikinya dalam memilih atau memprediksi secara deduktif berbagai kemungkinan akibat-akibat dari suatu fenomena, yang memuat sebuah atau beberapa penyebab yang diberikan, serta mampu mengidentifikasi bagaimana sebuah atau beberapa penyebab tersebut dapat menghasilkan suatu akibat yang terprediksi.

Berdasarkan hasil observasi dan wawancara dengan siswa dan guru fisika SMAN 8 Mataram, diperoleh bahwa mata pelajaran fisika sering dianggap sebagai pelajaran yang sulit dan membosankan karena identik dengan banyaknya persamaan yang harus dihafalkan. Hal ini sejalan dengan pendapat Hasbiyalloh et al. (2017) yang mengatakan bahwa Siswa juga sering 
menilai bahwa pelajaran fisika sangat sulit dan membosankan karena banyak rumusrumus yang harus dihafal dan dipahami, sehingga kenyataan yang dapat dilihat bahwa dalam hasil belajar fisika yang dicapai siswa masih rendah. Sementara itu, Setyowati et al. (2011) mengatakan bahwa mata pelajaran fisika dirasakan sulit oleh siswa, karena sebagian besar siswa belum mampu menghubungkan antara materi yang dipelajari dengan pengetahuan yang digunakan. Guru lebih menekankan pembelajaran yang memungkinkan siswa memiliki kemampuan sebatas dapat menjawab soal, akibatnya kemampuan pemecahan masalah siswa menjadi rendah.

Faktor lain yang menjadi penyebab rendahnya kemampuan pemecahan masalah siswa adalah pada pelaksanaan pembelajaran, siswa hanya diperkenalkan dengan rumus saja tanpa memahami materi. Masalah ini akan membawa pola pikir siswa pada pembelajaran sangat monoton, sehingga pembelajaran fisika menjadi kurang menarik dan banyak siswa tidak menyukainya. Padahal, pelajaran fisika dapat menjadi menarik jika guru dapat membuat siswa terlibat secara aktif untuk berpikir secara terbuka. Pembiasaan berpikir secara terbuka dapat memfasilitasi siswa untuk memahami konsep fisika secara utuh (Rokhmat et al. 2012).

Berdasarkan permasalahan tersebut, maka diperlukan suatu pendekatan pembelajaran yang dapat membuat siswa mengenal konsep fisika dengan berpikir secara divergen. Marwiyanto (2010) menyatakan bahwa berpikir divergen merupakan berpikir dalam arah yang berbeda-beda sehingga diperoleh banyak macam jawaban yang unik tetapi benar (dalam Wijaya et al. 2014). Salah satu pendekatan yang membuat siswa dapat berpikir secara divergen serta dapat mengembangkan kemampuan pemecahan masalah yaitu dengan pendekatan berpikir kausalitik.

Pendekatan berpikir kausalitik ini merupakan penggabungan suatu pemikiran dari berpikir kausalitas dan berpikir analitik. Pendekatan berpikir kausalitik memiliki 5 kelebihan yaitu siswa akan terlatih untuk: (1) menganalisis fenomena fisika; 2) memahami konsep secara menyeluruh; 3) berpikir secara kritis dan sintesis; 4) berpikir secara divergen; dan 5) menjawab permasalahan berdasarkan konsep fisika (Rokhmat, 2013).

Pendekatan berpikir kausalitik ini selain memiliki kelebihan juga memiliki kelemahan, yaitu siswa mengalami kesulitan dalam menjawab pertanyaan yang berbentuk kausalitik karena siswa belum terbiasa memberikan jawaban berupa alasan secara tepat. Untuk mengatasi kelemahan tersebut, maka siswa perlu diberikan suatu tahapan bantuan berupa scaffolding pada pola berpikir kausalitik tersebut. Mamin (2008) mengatakan bahwa pembelajaran scaffolding berarti memberikan kepada individu sejumlah besar bantuan selama bertahap-tahap awal pembelajaran dan kemudian mengurangi bantuan tersebut dan memberikan kesempatan kepada anak didik tersebut untuk mengambil alih tanggung jawab yang semakin besar, segera setelah mampu mengerjakan sendiri. Dalam diterapkannya pendekatan berpikir kausalitik ber-scaffolding ini masih belum berfungsi secara maksimal. Hal ini diduga dikarenakan kurangnya perhatian siswa dan tidak memahami materi yang akan dipelajari. Oleh karena itu, siswa perlu diberikan suatu tugas pendahuluan (TP). Tugas pendahuluan (TP) merupakan suatu pekerjaan yang diberikan oleh guru kepada siswa yang saat pra-tatap muka (Rokhmat, 2017). Karakteristik tugas pendahuluan (TP) disesuaikan dengan tujuannya, yaitu memfasilitasi siswa membangun konsepsi awal terhadap materi yang akan dijadikan 
pembahasan dalam pembelajaran (Rokhmat, 2018).

Rokhmat (2013) memperkenalkan 8 tipe pendekatan berpikir kausaliti (PBK-A) berscaffolding yaitu: 1) PBK-A ber-scaffolding tipe 1A, 2) PBK-A ber-scaffolding tipe 1B, 3) PBK-A ber-scaffolding tipe 2A, 4) PBK-A berscaffolding tipe 2B, 5) PBK-A ber-scaffolding tipe 3A, 6) PBK-A ber-scaffolding tipe 3B, 7) PBKA ber-scaffolding tipe 4A, dan 8) PBK-A berscaffolding tipe 4B. Untuk penelitian ini dengan mempertimbangkan kondisi siswa yang belum terbiasa belajar dengan pendekatan berpikir kausalitik, materi, dan jenjang pendidikan objek penelitian maka peneliti memilih untuk menggunakan PBK-A berscaffolding tipe 2B. Pola PBK-A yang peneliti gunakan adalah pola PBK-A ber-scaffolding tipe 2B yang termodifikasi.

PBK-A ber-scaffolding tipe 2B termodifikasi adalah pengembangan berpikir kausalitik dengan bantuan pola utama tabel kausalitas dengan jumlah akibat, sebagian komponen akibat, jumlah komponen penyebab, sebagian komponen penyebab serta sebagian penjelasan dari akibat diberikan. Modifikasi yang peneliti maksud dalam hal ini adalah pemberian informasi mengenai sebagian komponen penyebabnya.

Hasil penelitian ini diharapkan dapat memberikan manfaat bagi pembaca, guru, siswa dan peneliti lain yang ingin melaksanakan penelitian pada bidang kajian yang sama serta bermanfaat bagi pengembangan pembelajaran yang berorientasi peningkatan kemampuan pemecahan masalah fisika siswa.

\section{METODE PENELITIAN}

Jenis penelitian ini adalah quasi experiment dengan desain Posttest-Only Control Group Design. Populasi penelitian ini adalah seluruh siswa kelas X MIA SMA Negeri 8 Mataram dengan teknik pengambilan sampel menggunakan cluster random sampling, sehingga diperoleh 33 jumlah siswa kelas X MIA 1 sebagai kelas eksperimen dan 32 jumlah siswa kelas $\mathrm{X}$ MIA 3 sebagai kelas kontrol.

Penelitian ini melibatkan variabel bebas yaitu model pendekatan berpikir kausalitik ber-scaffolding dengan pemberian tugas pendahuluan, variabel terikat yaitu berupa kemampuan pemecahan masalah impuls dan momentum, dan variabel kontrol yaitu alokasi waktu, guru yang mengajar dan materi ajar.

Instrumen yang digunakan adalah tes kemampuan pemecahan masalah. Teknik pengumpulan data berupa tes tertulis berbentuk soal uraian. Tes kemampuan pemecahan masalah berjumlah 5 soal. Indikator pemecahan masalah (IPM) yang digunakan dalam tes ini terdiri dari enam indikator yaitu sebagai berikut: IPM-1 pemahaman (understanding), IPM-2 pemilihan (selecting), IPM-3 pembedaan (differentiating), IPM-4 penentuan (determining), IPM-5 penerapan (applying), dan IPM-6 pengidentifikasian (identifying). Nilai IPM siswa dapat dikategorikan berdasarkan tabel berikut.

Tabel 1. Kriteria Penilaian IPM

\begin{tabular}{cc}
\hline Skor & Keterangan \\
\hline $81-100$ & Sangat tinggi \\
$61-80$ & Tinggi \\
$41-60$ & Sedang \\
$21-40$ & Rendah \\
$0-20$ & Sangat rendah \\
\hline
\end{tabular}

Instrumen tes kemampuan pemecahan masalah sebelum digunakan harus memenuhi beberapa syarat yaitu uji validitas, reliabilitas, tingkat kesukaran dan daya beda soal. Uji analisis data menggunakan uji-t polled varians dengan taraf signifikan $5 \%$ dan derajat kebebasan $\left(n_{1}+n_{2}\right)-1$.

\section{HASIL DAN PEMBAHASAN}

Penelitian ini bertujuan untuk mengetahui pengaruh pendekatan berpikir 
kausalitik ber-scaffolding dengan pemberian tugas pendahuluan terhadap kemampuan pemecahan masalah impuls dan momentum siswa kelas X SMAN 8 Mataram tahun ajaran 2017/2018. Penelitian ini merupakan penelitian kuasi eksperimen yang dilakukan dengan memberikan perlakuan berupa pendekatan berpikir kausalitik berscaffolding dengan pemberian tugas pendahuluan pada kelas eksperimen (X MIA 1) dengan jumlah siswa 33 orang dan perlakuan berupa pembelajaran konvensional pada kelas kontrol (X MIA 3) dengan jumlah siswa 32 orang. Kedua kelas diberikan perlakuan selama tiga kali pertemuan dengan alokasi waktu setiap pertemuan selama 135 menit (3 jam pelajaran).

Dari hasil observasi yang telah dilakukan, model pembelajaran konvensional yang sering digunakan dalam proses pembelajaran yaitu model pembelajaran kooperatif. Pada Proses pembelajaran mengikuti sintak model pembelajaran tersebut. Proses pendekatan berpikir kusalitik ber-scaffolding untuk kelas eksperimen dilaksanakan pada sintak kedua dan keempat yaitu pada sintak menyajikan informasi dan pada sintak membantu kelompok kerja dan belajar. Pada sintak kedua, guru memberikan contoh fenomena fisika dan pada sintak keempat, siswa mengerjakan lembar kerja siswa (LKPD) yang telah disiapkan oleh guru yang disesuaikan dengan proses pendekatan berpikir kusalitik ber-scaffolding, yaitu dengan bantuan LKPD yang menyediakan fenomena fisika yang menuntut siswa untuk berpikir secara terbuka untuk dapat memecahkan fenomena tersebut. LKPD yang berisi tahapan bantuan ini berfungsi membantu siswa untuk menyesuaikan diri dengan pola pembelajaran dengan pendekatan berpikir kausalitik berscaffolding. Scaffolding yang digunakan dalam penelitian ini adalah scaffolding tipe
2B termodifikasi dimana pada LKPD berisi tabel kausalitas yang memuat bantuanbantuan untuk menyelesaikan permasalahan atau fenomena fisika berupa informasi sebagian komponen penyebab, sebagian komponen akibat, jumlah komponen penyebab dan akibat, serta contoh penjelasan.

Penelitian kemampuan pemecahan masalah ini mengukur enam indikator yang meliputi: (1) pemahaman yaitu kemampuan siswa memahami ide atau gagasan dalam setiap soal; (2) pemilihan yaitu kemampuan siswa dalam memilih penyebab-penyebab dan/atau memprediksi berbagai kemungkinan akibat yang dapat terjadi berkenaan dengan kondisi penyebab dalam soal atau fenomena fisika; (3) pembedaan yaitu kemampuan siswa dalam membedakan dan memilih penyebabpenyebab yang dapat menghasilkan suatu akibat tertentu; (4) penentuan yaitu kemampuan menentukan konsep, prinsip, teori, dan/atau hukum fisika yang dapat digunakan untuk mendukung dalam mengidentifikasi sebuah atau beberapa penyebab sehingga menghasilkan suatu akibat; (5) penerapan yaitu kemampuan siswa dalam menggunakan konsep, prinsip, teori, dan/atau hukum fisika yang diperlukan dalam mengidentifikasi penyebab-penyebab sehingga menghasilkan suatu akibat tertentu; dan (6) pengidentifikasian yaitu kemampuan mengidentifikasi kondisi penyebabpenyebab sehingga dapat menghasilkan suatu akibat tertentu.

Data hasil kemampuan pemecahan masalah (KPM) siswa diperoleh setelah diberikan perlakuan berupa pendekatan berpikir kausalitik ber-scaffolding. Tes KPM yang diberikan berupa tes tertulis yang berbentuk tes uraian sebanyak 5 soal. Sebelum diberikan tes pada kelas kontrol dan kelas eksperimen, peneliti terlebih dahulu melakukan uji coba instrumen sebanyak 5 soal pada kelas XI MIPA 1 di 
SMAN 5 Mataram. Data hasil uji coba instrumen ini kemudian dilakukan uji validasi dan reliabilitas. Uji validasi terdiri dari validasi ahli dan validasi empiris, untuk validasi ahli berupa LKPD ber-scaffolding tipe $2 b$ modifikasi, data tes kemampuan pemecahan masalah, dan RPP, sedangkan untuk validasi empiris berupa tes kemampuan pemecahan masalah. Selanjutnya uji reliabilitas dilakukan untuk mengetahui reliabel atau tidak reliabelnya tes tersebut. Sebuah tes dikatakan reliabel bila tes tersebut dapat dipercaya. Berdasarkan hasil uji coba instrumen tersebut terdapat semua item soal yang valid dan reliabel. Sehingga peneliti menyimpulkan untuk mengambil kelima soal tersebut untuk melakukan tes KPM pada kelas eksperimen dan kelas kontrol.

Berdasarkan hasil penelitian untuk tes kemampuan pemecahan masalah, kelas eksperimen memperoleh nilai rata-rata sebesar 65 dengan nilai tertinggi 87 dan nilai terendah 40, kelas kontrol memperoleh nilai rata-rata sebesar 53 dengan nilai tertinggi 70 dan nilai terendah 37 . Nilai rata-rata tersebut menunjukkan bahwa ada perbedaan yang signifikan setelah kelas eksperimen diberikan perlakuan. Hal ini dapat dilihat dari uji statistik yang digunakan yaitu uji-t polled varians. Hasil perhitungan menunjukkan bahwa nilai $t_{\text {hitung }}>\mathrm{t}_{\text {tabel }}$ yaitu 3,37>1,99. Berdasarkan kriteria bahwa jika $t_{\text {hitung }}>t_{\text {tabel }}$ maka $\mathrm{H}_{\mathrm{o}}$ ditolak dan $\mathrm{H}_{\mathrm{a}}$ diterima, hasil uji tersebut menunjukkan adanya pengaruh pendekatan berpikir kausalitik berscaffolding dengan pemberian tugas pendahuluan terhadap kemampuan pemecahan masalah impuls dan momentum siswa kelas X SMAN 8 Mataram tahun ajaran 2017/2018, sehingga dapat diketahui bahwa pendekatan berpikir kausalitik berscaffolding dengan pemberian tugas pendahuluan ini berpengaruh positif terhadap kemampuan pemecahan masalah fisika siswa. Hasil penelitian ini didukung oleh penelitian terdahulu yang telah dilaksanakan oleh Rokhmat et al. (2017) yang menyatakan bahwa adanya perbedaan signifikan antara hasil pretest dan posttest kemampuan pemecahan masalah untuk kelas bawah dan kelas atas pada mahasiswa calon guru fisika, dan penelitian yang dilakukan oleh Helmi, (2017:72) yang menyatakan bahwa pembelajaran dengan pendekatan berpikir kausalitik berscaffolding tipe 2B termodifikasi berbantuan LKPD memberikan pengaruh positif terhadap kemampuan pemecahan masalah fluida dinamis siswa kelas XI tahun pelajaran 2016/2017.

Berdasarkan hasil analisis data yang diperoleh selama penelitian menunjukkan bahwa pembelajaran dengan menerapkan pendekatan berpikir kausalitik memberikan pengaruh lebih baik terhadap kemampuan pemecahan masalah fisika siswa. Hal ini dapat disebabkan dalam penerapan pendekatan berpikir kausalitik dilakukan dengan berbantuan Lembar Kerja Siswa (LKPD) ber-scaffolding tipe 2b modifikasi. Jadi, selain siswa dilatih berpikir kausalitas dan analitik dalam kegiatan pembelajaran, siswa juga ditunjang dengan menggunakan media LKPD yang didalamnya terdapat fenomena fisika dengan diberikan bantuan berupa tabel kausalitas dan bantuan tahapan berupa sebagian komponen akibat, sebagian komponen penyebab, dan sebagian penjelasan mengenai terjadinya suatu akibat. Data hasil kemampuan pemecahan masalah fisika siswa yang diperoleh selama penelitian jika dikaitkan dengan keenam indikator yang merupakan aspek kemampuan pemecahan masalah yang harus dicapai siswa, didapat bahwa pada IPM-1 dan IPM-2 untuk kedua kelas yaitu dalam kategori baik sekali. Pada IPM-3 untuk kedua kelas dalam kategori baik. Pada IPM4 dan IPM-5 untuk kelas eksperimen dalam kategori kurang sedangkan untuk kelas kontrol dalam kategori sangat kurang. Pada 
IPM-6 untuk kedua kelas dalam kategori sangat kurang. Berdasarkan hasil analisis tersebut, terlihat bahwa kelas eksperimen memiliki persentase nilai rata-rata lebih tinggi dibandingkan dengan kelas kontrol.

Tabel 2. Persentase Nilai Rata-rata KPM Siswa Tiap Indikator

\begin{tabular}{ccccccc}
\hline \multirow{2}{*}{ Data } & \multicolumn{6}{c}{ Nilai Rata-rata Kemampuan Pemecahan Masalah (\%) } \\
& IPM-1 & IPM-2 & IPM-3 & IPM-4 & IPM-5 & IPM-6 \\
\hline Eksperimen & 100 & 96 & 82 & 44 & 41 & 25 \\
Kontrol & 96 & 95 & 80 & 22 & 15 & 1 \\
\hline
\end{tabular}

Hasil tes KPM pada kelas eksperimen menunjukkan bahwa pada IPM-4 dan IPM-5 masih dalam kategori kurang. Hal ini dikarenakan pada IPM-4 dan IPM-5, siswa tidak dapat menentukan dan menuliskan konsep, prinsip, teori, dan/atau hukum fisika yang digunakan untuk menyelesaikan suatu permasalahan atau fenomena fisika serta kemampuan siswa dalam menggunakan konsep, prinsip, teori, dan/atau hukum fisika yang diperlukan dalam mengidentifikasi penyebab-penyebab sehingga menghasilkan suatu akibat tertentu. Sedangkan persentase kemampuan pemecahan masalah pada IPM-6 untuk kelas eksperimen dalam kategori sangat kurang. Hal ini dikarenakan indikator tersebut merupakan indikator yang membutuhkan pengetahuan yang cukup tinggi. Berikut ini salah satu contoh jawaban yang diberikan oleh siswa pada nomor 5 .

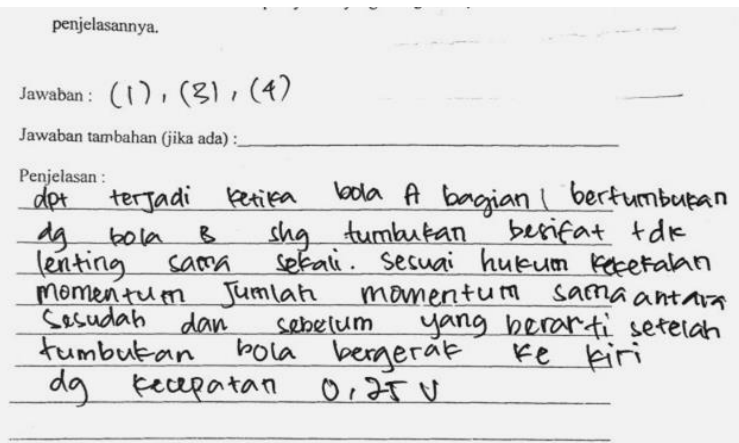

Gambar 1. Contoh Jawaban Siswa pada Nomor 5

Gambar 1 menunjukkan bahwa pola jawaban siswa yang sering ditulis adalah siswa hanya memberikan sebagian dari beberapa penjelasan akibat yang dipilih. Hal tersebut menyebabkan siswa kehilangan nilai pada IPM-6. Hal tersebut terjadi karena kemungkinan siswa tidak memahami konsep, prinsip, teori dan/atau hukum fisika yang digunakan dalam menyelesaikan suatu permasalahan atau siswa kehabisan waktu untuk menjawab pertanyaan tersebut.

Untuk mengatasi keterbatasan hal tersebut, diperlukan sebuah strategi saat memberikan perlakuan yaitu dengan memberikan penekanan-penekanan pada IPM-5 dan IPM-6. IPM-5 tentang bagaimana siswa menggunakan konsep, prinsip, teori, dan/atau hukum-hukum fisika dan IPM-6 tentang bagaimana siswa dalam mengidentifikasi kondisi penyebabpenyebab sehingga dapat menghasilkan suatu akibat. Selain itu, pembelajaran ini juga membutuhkan waktu yang cukup lama untuk membahas satu permasalahan sehingga perlu sekali untuk mengatur kembali alokasi waktu pembelajarannya. Hal tersebut biasanya terjadi karena siswa belum terbiasa menggunakan pendekatan berpikir kausalitik dalam pembelajarannya. Sehingga waktu pembelajaran terbuang untuk menjelaskan bagaimana cara belajar menggunakan pendekatan ini. Untuk mengatasi hal tersebut, siswa perlu diberikan pemahaman tentang bagaimana metode belajar dengan pendekatan kausalitik ini sehingga proses pembelajaran berjalan secara optimal.

\section{PENUTUP}

Berdasarkan uji hipotesis, dapat disimpulkan bahwa terdapat pengaruh 
pendekatan berpikir kausalitik berscaffolding dengan pemberian tugas pendahuluan terhadap kemampuan pemecahan masalah siswa kelas X SMAN 8 Mataram terutama pada materi impuls dan momentum.

\section{REFERENSI}

Hasbiyalloh, A. S., Harjono, A., \& Verawati, N. N. S. P. 2017. Pengaruh Model Pembelajaran Ekspositori Berbantuan Scaffolding dan Advance Organizer Terhadap Hasil Belajar Fisika Peserta Didik Kelas X. Jurnal Pendidikan Fisika dan Teknologi, 3(2), 173-180.

Helmi, F., \& Rokhmat, J. 2017. Pengaruh Pendekatan Berpikir Kausalitik Berscaffolding Tipe 2b Termodifikasi Berbantuan LKS Terhadap Kemampuan Pemecahan Masalah Fluida Dinamis Siswa. Jurnal Pendidikan Fisika dan Teknologi, 3(1), 68-75.

Mamin, R. 2008. Penerapan Metode Pembelajaran Scaffolding Pada Pokok Bahasan Sistem Periodik Unsur. CHEMICA. 10(2), 56-60.

Rokhmat, J. 2013. Kemampuan Proses Berpikir Kausalitas dan Berpikir Analitik Mahasiswa Calon Guru Fisika. Jurnal Pengajaran MIPA, 18(1), 78-86.

Rokhmat, J. 2013. Peningkatan Kemampuan Pemecahan Masalah Mahasiswa Calon Guru Fisika melalui Berpikir Kausalitas dan Analitik. Disertasi. Universitas Pendidikan Indonesia: tidak diterbitkan.

Rokhmat, J. 2017. Fisika Dasar dengan Pendekatan Kausalitik. Mataram: Arga Puji Press.

Rokhmat, J. 2018. Model Pembelajaran Kausalitik Berorientasi Penguasaan Konsep Secara Utuh Disertai Contoh Pengembangan Instrumen untuk Pembelajaran Fisika. Mataram: Arga Puji Press.

Rokhmat, J., Marzuki, Hikmawati, \& Verawati, N.N.P.S. 2017. The Causal Model in Physics Learning with a Causaliticthinking Approach to Increase the Problem-solving Ability of Pre-service Teachers. Pertanika Journal Social Sciences \& Humantities, 25(s), 153-168

Rokhmat, J., Rusdiana, D., \& Setiawan, A. 2012. Pembelajaran Fisika Berbasis Proses Berpikir Kausalitas Dan Berpikir Analitik (PBK-BA), Suatu Pembiasaan Berpikir Secara Terbuka. Seminar Nasional IX Pendidikan Biologi FKIP UNS, 9(1).

Setyowati, A., \& Subali, B. 2011. Implementasi pendekatan konflik kognitif dalam pembelajaran fisika untuk menumbuhkan kemampuan berpikir kritis siswa SMP kelas VIII. Jurnal Pendidikan Fisika Indonesia, 7(2), 89-96.

Venisari, R., Gunawan, G., \& Sutrio, S. 2015. Penerapan Metode Mind Mapping pada Model Direct Instruction untuk Meningkatkan Kemampuan Pemecahan Masalah Fisika Siswa SMPN 16 Mataram. Jurnal Pendidikan Fisika dan Teknologi, 1(3), 193-199.

Wijaya, I. K. W. B., Suastra, I. W., \& Muderawan, I. W. 2014. Pengaruh Model Pembelajaran Generatif terhadap Keterampilan Berpikir Kreatif dan Keterampilan Proses Sains. Jurnal Pendidikan dan Pembelajaran IPA Indonesia, 4(1). 